\title{
DETERMINATION OF AN OPTIMAL PLAN FOR SUPPLYING AN INFANTRY BATTALION IN COMBAT CONDITIONS
}

\author{
Alina BABOȘ, Alexandru BABOȘ \\ "Nicolae Bălcescu" Land Forces Academy, Sibiu, Romania \\ alina_babos_24@yahoo.com, babos.alexandru@yahoo.com
}

\begin{abstract}
The modern battle field is characterized by an increasing number of indispensable information in decision making process, and as a consequence the increasing importance of software components in weapons systems. Under current conditions the commander can not only rely on experience and intuition, so it needs an information-based analytical thinking and reasoning. In this context, the operational research, with its methods and models, represents the scientific basis on which a rational and optimal decision is supported, by involving a minimal risk. This paper presents the optimization of military action, showing how to solve a practical problem using the transportation problem. The paper combines mathematical methods for solving the problem of transport with the requirements imposed by the tactical situations parameters encountered in the course of military operations by exemplifying a complex military operation.
\end{abstract}

Keywords: optimization, transport, infantry battalion.

\section{Introduction}

Emerged of military necessity, the operational research, is dealing essentially with the optimization of the decisions by using mathematical modelling and data supplied by a generic action called operation.

The transport problem finds its application in situations where the upper echelons must draw up an optimal plan of resources allocation for means of fighting on objectives. In order to achieve more reliable results for the real problem, the data needed to formulate the mathematical model are extracted from an order of operations.

2. Overall tactical situation. The problem formulation

A motorized infantry battalion of Polish Army equipped with AMV Rosomak is running defensive on national territory. HQ predicts that the action will stretch over a period of 3 days in heavy fighting conditions. The battalion logistics structure must draw up a plan to ensure efficient logistical support to combat. This support is to ensure the 3 fighting companies with ammunition, fuel, water and food. The logistics company's goal is to deliver all of the materials from the supply point at battalion level towards the companies supply points from where the subunits will be later delivered depending on the demand.

In preparing this plan the difficult conditions of combat, the difficulty of accessing the roads necessary for materials transportation, the available technique used for transportation, the climate, and of course the expected loss will be taking into consideration. Of course, the main objective is to achieve minimum costs. A battalion is organized according to Table 1 .

Logistics Company include: command crew vehicle, a supply platoon and a maintenance platoon. In this situation, according to Table 1, the supply platoon has at its disposal 21 trucks of $3.5(\mathrm{t})$ capacity, 3 
water tanks of 3000 (1) and 3 fuel tanks of 4500 (1). The supplies transportation is made on three routes D1, D2 and D3.

\section{Centralizing data. Solving the problem}

The quantities of supplies needed for each category (ammunition, fuel, food and water) will be calculated.

Calculation of ammunition will be carried out using the data in Table 1 on the

Table 1: Organization of a motorized infantry battalion / AMV - Rosomak

\begin{tabular}{|c|c|c|c|c|c|c|c|}
\hline Specifications & $\begin{array}{c}\text { Team } \\
\text { Recc(UAV } \\
)\end{array}$ & Staff & $\begin{array}{c}\text { Team } \\
\text { fighters } x \\
4 \\
\end{array}$ & $\begin{array}{l}\text { Suport } \\
\text { comp }\end{array}$ & Logistic & Med & TOTAL \\
\hline Personnel & 4 & 66 & 130 & 100 & 78 & 16 & 784 \\
\hline \multicolumn{8}{|c|}{ Weapons } \\
\hline $9 \mathrm{MM}$ gun $\mathrm{PW}$ & 4 & 18 & 20 & 26 & 15 & 8 & 151 \\
\hline 9 MM gun $\mathrm{PM}$ & & 10 & 39 & 12 & 2 & 8 & 188 \\
\hline 5,56 MM asalt wpn. kbk Beryl & 4 & 52 & 82 & 72 & 76 & & 532 \\
\hline P.S.L7,62 MM kbk AK SWD & & & & 12 & & & 12 \\
\hline 7,62 MM Machinegun PK & & & 3 & & & & 12 \\
\hline 7,62 MM Machinegun PKS & & 4 & 6 & 2 & & & 30 \\
\hline RPG- 76 & & 5 & 12 & 2 & & & 55 \\
\hline \multicolumn{8}{|c|}{ Technical and equipment } \\
\hline Transport Carrier AMV & & 1 & 13 & 3 & & & 56 \\
\hline TAB BRDM & & 3 & & & & & 3 \\
\hline Motorcycle & & 1 & & & & & 1 \\
\hline Convertible with 4 wheel drive & & 2 & & & & & 2 \\
\hline Tactical radar & & 1 & & & & & 1 \\
\hline Launcher PPK SPIKE & & & & 6 & & & 6 \\
\hline Mortier $98 \mathrm{MM}$ & & & & 6 & & & 6 \\
\hline Telemeter with laser & & 1 & & 2 & & & 3 \\
\hline Command vehicle & 1 & 2 & & 1 & 1 & & 5 \\
\hline Radiotelephone UKF & 1 & 3 & & 14 & 6 & 4 & 28 \\
\hline Radiostation UKF kp & & 10 & 20 & 13 & 2 & & 105 \\
\hline Tractor CKE & & & & & 1 & & 1 \\
\hline Large transport vehicle & & 8 & 2 & 6 & 21 & & 43 \\
\hline Small transport vehicle & & & & & 1 & & 1 \\
\hline Water tank 30001 & & & & & 3 & & 3 \\
\hline Fuel tank & & & & & 3 & & 3 \\
\hline Ambulance & & & 1 & & & 3 & 7 \\
\hline Electricity generator & & 1 & & & 2 & & 3 \\
\hline Total equipments & 2 & 33 & 36 & 51 & 40 & 7 & 211 \\
\hline
\end{tabular}

Table 2: Calculation of ammo rations and quantity

\begin{tabular}{|l|r|r|r|}
\hline \multirow{2}{*}{ Table 2: Calculation of ammo rations and quantity } \\
\cline { 2 - 4 } & \multicolumn{3}{|c|}{ Battalion AMV Rosomak } \\
\cline { 2 - 4 } & Quantity & Mass UC /kg & $\begin{array}{c}\text { Transport } \\
\text { coefficient }\end{array}$ \\
\hline 9 MM gun PW & $\mathbf{1 7 3}$ & 8,30 & 0,02 \\
\hline 9 MM gun PM & $\mathbf{1 8 8}$ & 67,68 & 0,14 \\
\hline 5,56 MM asalt wpn. kbk Beryl & $\mathbf{5 5 4}$ & 531,84 & 1,06 \\
\hline P.S.L7,62 MM kbk AK SWD & $\mathbf{1 2}$ & 7,20 & 0,01 \\
\hline 7,62 MM Machinegun PK & $\mathbf{1 2}$ & 65,52 & 0,13 \\
\hline 7,62 MM Machinegun PKS & $\mathbf{3 0}$ & 326,70 & 0,65 \\
\hline RPG- 76 & $\mathbf{8 0}$ & 80,00 & 0,08 \\
\hline Total ammo/weapons & & $\mathbf{1 0 1 8 , 7 6}$ & $\mathbf{2 , 0 4}$ \\
\hline \multirow{2}{*}{ TAB BRDM } & $\mathbf{3}$ & 108,00 & 0,11 \\
\hline AMV Rosomak carrier & $\mathbf{3}$ & 36,00 & 0,04 \\
\hline Total ammo for carriers & $\mathbf{5 6}$ & 896,00 & 0,90 \\
\hline
\end{tabular}

It will therefore deduct the formula: $\mathrm{F}(\mathrm{kg}) \cdot \mathrm{N}=\mathrm{UC}(\mathrm{kg})$ where UF- Fire weight of each category of weapons in hand, $\mathrm{N}$ - the number of copies from the same category and UC- Fire weight for all the weapons in the same category. By doing so, the results from Table 2 will be obtained. 
Table 3: The fuel daily ration for each category of military equipment

\begin{tabular}{|c|c|c|c|c|c|c|}
\hline \multirow{2}{*}{ Vehicle type/Equip. } & \multirow{2}{*}{ Measure RZ } & \multicolumn{2}{|c|}{$\mathbf{R Z}$} & \multicolumn{2}{|c|}{ Capacity } & \multirow{2}{*}{ No. of RZ } \\
\hline & & $/ \mathbf{d m}^{3} /$ & $/ \mathrm{kg} /$ & $/ \mathbf{d m}^{3} /$ & $/ \mathrm{kg} /$ & \\
\hline \multicolumn{7}{|c|}{ Wheeled Vehicles } \\
\hline TAB BRDM & {$\left[\mathrm{dm}^{3} / 100 \mathrm{~km}\right]$} & 39,0 & 29,3 & 290,0 & 217,5 & 7,4 \\
\hline Convertible vehicle Honda & {$\left[\mathrm{dm}^{3} / 100 \mathrm{~km}\right]$} & 10,0 & 7,5 & 17,0 & 12,8 & 1,7 \\
\hline Motorcycle ETZ & {$\left[\mathrm{dm}^{3} / 100 \mathrm{~km}\right]$} & 3,0 & 2,3 & 12,5 & 9,4 & 4,2 \\
\hline $\begin{array}{l}\text { Large transport vehicle } \\
\text { Star-660 }\end{array}$ & {$\left[\mathrm{dm}^{3} / 100 \mathrm{~km}\right]$} & 40,0 & 30,0 & 300,0 & 225,0 & 7,5 \\
\hline AMV Rosomak carrier & {$\left[\mathrm{dm}^{3} / 100 \mathrm{~km}\right]$} & 87,0 & 74,0 & 304,0 & 258,4 & 3,5 \\
\hline Tractor & {$\left[\mathrm{dm}^{3} / 12 \mathrm{mtg}\right]$} & 9,5 & 8,1 & 50,0 & 42,5 & 5,3 \\
\hline Medium vehicle Kraz & {$\left[\mathrm{dm}^{3} / 100 \mathrm{~km}\right]$} & 55,0 & 46,8 & 330,0 & 280,5 & 6,0 \\
\hline Small vehicle Landrover & {$\left[\mathrm{dm}^{3} / 100 \mathrm{~km}\right]$} & 13,0 & 11,1 & 170,0 & 144,5 & 13,1 \\
\hline $\begin{array}{l}\text { Command vehicle } \\
\text { Mercedes B-1300 }\end{array}$ & {$\left[\mathrm{dm}^{3} / 100 \mathrm{~km}\right]$} & 25,0 & 21,3 & 160,0 & 136,0 & 6,4 \\
\hline $\begin{array}{l}\text { Ambulance AMV } \\
\text { Rosomak }\end{array}$ & {$\left[\mathrm{dm}^{3} / 100 \mathrm{~km}\right]$} & 87,0 & 74,0 & 304,0 & 258,4 & 3,5 \\
\hline Water tank Sam. Star-200 & {$\left[\mathrm{dm}^{3} / 100 \mathrm{~km}\right]$} & 21,0 & 17,9 & 150,0 & 127,5 & 7,1 \\
\hline $\begin{array}{l}\text { Fuel tank Sam. Star-266 } \\
\text { CT }\end{array}$ & {$\left[\mathrm{dm}^{3} / 100 \mathrm{~km}\right]$} & 31,0 & 26,4 & 300,0 & 255,0 & 9,7 \\
\hline
\end{tabular}

Table 4: Table with the known average for the coefficients

\begin{tabular}{|c|c|}
\hline Coefficient category & Coefficient value \\
\hline \multicolumn{2}{|c|}{ Military operations type $/ \mathbf{C}_{\text {op. }}$} \\
\hline Offense & 2,5 \\
\hline Defence & 2,0 \\
\hline Movement & 1,5 \\
\hline Action to slow the enemy & 1,0 \\
\hline \multicolumn{2}{|c|}{ Land type $/ C_{t /}$} \\
\hline Plain & 1,0 \\
\hline Hill & 1,2 \\
\hline Mountain & 1,5 \\
\hline \multicolumn{2}{|c|}{ Climate type $/ \mathrm{C}_{\mathrm{c} /}$} \\
\hline Tropical & 0,9 \\
\hline Temperate & $\mathbf{1 , 0}$ \\
\hline Winter & 1,3 \\
\hline
\end{tabular}

ammunition to be transported.

If we add the total UC all that we have achieved is $1018.76(\mathrm{~kg})$ ammunition for individual weapons and $1040(\mathrm{~kg})$ ammunition for fighting machines and conveyors, so a total of $2058.76(\mathrm{~kg})$. On the last column in Table 2 are the transport coefficients expressing the volumetric characteristics of ammunition crates to be loaded on trucks. By collecting all coefficients we reach a unique coefficient for ammunition, in this case 3.08. This factor is multiplied by the total quantity of ammunition and results in a final weight of $6350(\mathrm{~kg})$ for a day of battle. Multiplying by 3 we reach a weight of $19050 \quad(\mathrm{~kg})$
Calculation of the quantity fuel is performed using the information in Table 3 which contains the daily rations for each type of used technique. The RZ formula will be used, $\mathrm{RZ}(\mathrm{kg}) \cdot \mathrm{N}=\mathrm{RZC}$, where RZweight of the daily fuel ration for each technical element, $\mathrm{N}$-number of items in the same category RZC the total amount of allocated items in a category. For the four fighter companies we have $134=52$ AMV Rosomak, $24=8$ trucks and 4 ambulances. So we calculate for each category: $74(\mathrm{~kg}) \cdot 52=3848(\mathrm{~kg}), 46,8(\mathrm{~kg}) \cdot 8=374,4 \quad(\mathrm{~kg})$ and $74(\mathrm{~kg}) \cdot 8=592(\mathrm{~kg})$. By summing these 
values we obtain a weight of $4814 \mathrm{~kg}$. In the forecasting process regarding the fuel consumption we will take into account the following external factors:

The coefficient for the type of military operation;

for the type of land;

The coefficient

coefficient.

\section{Climate}

These factors have known standard values; thereby we choose from the table (Table 4) those values for the type of military operation undertaken, the type of terrain and specific climatic factor. Thus follows: $4814,4(\mathrm{~kg}) \cdot 2 \cdot 1,5 \cdot 1=14443,2(\mathrm{~kg})$ for a day of fighting that total $43330(\mathrm{~kg})$ for 3 days.

For the calculation of the amount of food: a military consumes 3 meals daily $(3 \times 0,33 \mathrm{Kg})$ which weigh about one kilogram. In this situation the chosen solution is the use of food packages prepared in advance which will be transported and distributed. The result is obtained simply by multiplying the number of troops from a company with number of companies and the weight of the 3 daily meals: $130 \cdot 4 \cdot 1(\mathrm{~kg})=520(\mathrm{~kg})$ for 1 day respectively $1560(\mathrm{~kg})$ for 3 days.

The minimum amount of water required is 31 ,so he calculation of the amount of water required is $130.4 \cdot 3$ $(\mathrm{kg})=1560(\mathrm{~kg})$ for 1 day, respectively 4680 $(\mathrm{kg})$ for 3 days.

Given the quantities of supplies we can calculate the total weight to be transported towards the 3 supply points: $19050(\mathrm{~kg})$ ammo $+43330 \quad(\mathrm{~kg})$ fuel +1560 $(\mathrm{kg})$ food $+4680(\mathrm{~kg})$ water $=68620(\mathrm{~kg})$ supplies.

The designated routes for transport are the following:: D1-road in mountainous terrain, inaccessible, distance $20(\mathrm{~km})$; D2road in mountainous terrain of medium difficulty, distance $17(\mathrm{~km})$; D3-accessible road in hilly area, distance $21(\mathrm{~km})$. We have the 4 sources (M-ammunition, fuel-C, $\mathrm{H}-\mathrm{A}$-food and water) wherefrom shipments to the 3 recipients will be made (KPZpoints for supply for companies).

Knowing all that data: UC-unit consumption expressed in 1 needed to lead one element of military equipment on a distance of $100 \mathrm{~km}$ (is specific to each category of vehicle); Cop - The coefficient for the type of military operation; $\mathrm{Ct}$ - The coefficient for the type of land; CCcoefficient climate; CCC - Fuel consumed, the calculation of fuel / $100 \mathrm{~km}$ for each category of military equipment will be done using the following formula:

$$
\text { UC (1) } \mathrm{C} \mathrm{C}_{\mathrm{op}} \times \mathrm{C}_{\mathrm{t}} \times \mathrm{C}_{\mathrm{c}}=\mathrm{CCC} \text { (1) (1) }
$$

Knowing that the unit price of diesel is 5 zloty / liter and ammunition is transported by truck route D1, the transportation costs are calculated as follows:

$\mathrm{CCC}(1) \cdot(2 \mathrm{D} 1 / 100(\mathrm{~km})) \cdot 5(\mathrm{zl})=55 \cdot 2 \cdot 1$ $, 5 \cdot 1 \cdot(2 \cdot 20 / 100) \cdot 5=165 \cdot 0,4 \cdot 5=330 \quad(\mathrm{zl})$. For the D2 route we have $\operatorname{CCC}(1) \cdot(2 \mathrm{D} 2 / 100)$ $(\mathrm{km})$

)$\cdot 5(\mathrm{zl})=55 \cdot 2 \cdot 1,5 \cdot 1 \cdot(2 \cdot 17 / 100) \cdot 5=165 \cdot 0,34 \cdot 5=$ $280(\mathrm{zl})$. We proceed the same for D3, by mentioning that the coefficient for the road conditions change: $\mathrm{CCC}(1) \cdot(2 \mathrm{D} 3 / 100)$ $(\mathrm{km})) \cdot 5(\mathrm{zl})=55 \cdot 2 \cdot 1,2 \cdot 1 \cdot(2 \cdot 21 / 100) \cdot 5=132 \cdot 0,4$ $2 \cdot 5=277(\mathrm{zl})$.

By using the same method for sources $\mathrm{C}, \mathrm{H}$ and $\mathrm{A}$, we obtain the following costs, ordered in Table 5.

Table 5: Table with the known average for the coefficients

\begin{tabular}{|c|c|c|c|c|}
\hline SOURCES/DEST. & KPZ31 & KPZ32 & KPZ33 & STOCK (T) \\
\hline M & 330 & 280 & 277 & $\mathbf{1 9}$ \\
\hline C & 186 & 158 & 156 & $\mathbf{4 3}$ \\
\hline H & 330 & 280 & 277 & $\mathbf{2}$ \\
\hline A & 126 & 107 & 106 & $\mathbf{5}$ \\
\hline NEEDED (T) & $\mathbf{2 3}$ & $\mathbf{2 3}$ & $\mathbf{2 3}$ & $\mathbf{6 9}(\mathbf{T})$ \\
\hline
\end{tabular}


To the same table we added a column that contains quantities of supplies in each source. The objective being to distribute the entire amount of supplies to recipients equally, the last line was completed with the incumbent amount for each recipient in part as follows: 68620 $(\mathrm{kg}) / 3=\approx 69(\mathrm{t}) / 3=23(\mathrm{t})$. By having this data we can consider this case to be transposed from the practical case offered by the battalion ordinary logistic process.

Due to the fact that the minimum cost for transport is desired and the minimal operative time used we appeal to the minimum line method in order to find the initial basis solution:

Table 6: Table with initial solution and intermediate computations

\begin{tabular}{|c|c|c|c|c|}
\hline SOURCES/DEST. & KPZ31 & KPZ32 & KPZ33 & STOCK (T) \\
\hline $\mathrm{M}$ & 330 & 280 & $\underline{277 / \mathbf{1 9}}$ & 190 \\
\hline $\mathrm{C}$ & $\underline{186 / \mathbf{1 6}}$ & $\underline{158 / \mathbf{2 3}}$ & $\underline{156 / 4}$ & 4339160 \\
\hline $\mathrm{H}$ & $\underline{330 / 2}$ & 280 & 277 & $z 0$ \\
\hline $\mathrm{A}$ & $\underline{126 / 5}$ & 107 & 106 & 50 \\
\hline NEEDED(T) & 23750 & 230 & 23420 & $69(\mathrm{~T})$ \\
\hline
\end{tabular}

$630=13$

By applying the minimum line method we reached the following initial basis solution:

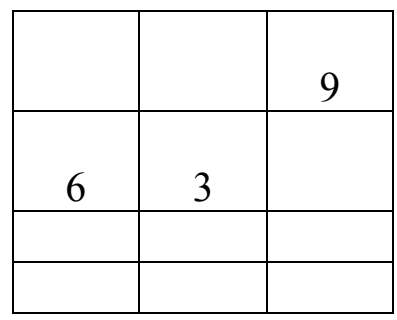

Starting from this solution, the next step will be the optimization of the final result. We check if the solution is degenerated or not with the formula $m+n$ $l=$ number of values, $x_{i j}>0$ so: $4+3-1=6$ bigger values then $0(19,16,23,4,2$ and 5$)$ so it results in a non-degenerated solution. Next, we directly apply the distributive method. The aim function is calculated as follows:

$$
F_{\text {min }}=0 \cdot 330+0 \cdot 280+19 \cdot 277+16 \cdot 186+
$$

$23 \cdot 158+4 \cdot 156+2 \cdot 330+0 \cdot 280+0 \cdot 277+5 \cdot 126+$ $0 \cdot 107+0 \cdot 106=5263+2976+3634+624+660+$
787.The regular solution is to be found in Table 7, so it can be optimized

By calculating the following differences, we check if the solution is optimal $\Delta_{i j}$ :

$$
\begin{aligned}
& \Delta_{11}=330-277+156-186=23 \\
& \Delta_{12}=280-277+156-158=1 \\
& \Delta_{32}=280-330+186-158=-
\end{aligned}
$$

22(negative difference)

$$
\Delta_{33}=277-330+186-156=-
$$

23(negative difference)

$$
\begin{aligned}
& \Delta_{42}=107-126+186-158=9 \\
& \Delta_{43}=106-126+186-156=50
\end{aligned}
$$

Next, we adjust the negative differences, $\Delta_{32}=-22$ and $\Delta_{33}=-23$. Given the fact that not all $\Delta_{i j}$ are positive, it means that the initial basis solution is not optimal. 
Table 7: Table used for optimizing the initial solution

\begin{tabular}{|c|c|c|c|c|}
\hline SOURCES/DEST. & KPZ31 & KPZ32 & KPZ33 & STOCK (T) \\
\hline $\mathrm{M}$ & 330 & 280 & $277 / \mathbf{1 9}$ & 19 \\
\hline $\mathrm{C}$ & $186 / \mathbf{1 6}$ & $158 / \mathbf{2 3}$ & $156 / \mathbf{4}$ & 43 \\
\hline $\mathrm{H}$ & $330 / \mathbf{2}$ & 280 & 277 & 2 \\
\hline $\mathrm{A}$ & $126 / \mathbf{5}$ & 107 & 106 & 5 \\
\hline NEEDED (T) & 23 & 23 & 23 & $69(\mathrm{~T})$ \\
\hline
\end{tabular}

The negative difference was given by the $\Delta_{32}=-22$ box, so the cycle will be formed starting from this box, as:

\begin{tabular}{|c|c|c|c|c|}
\hline & kpz31 & kpz32 & kpz33 & $\begin{array}{c}\text { STOCK } \\
(\mathrm{t})\end{array}$ \\
\hline $\mathrm{M}$ & & & 19 & 19 \\
\hline $\mathrm{C}$ & $\begin{array}{c}16 \\
+2\end{array}$ & 23 & 4 & 43 \\
\hline $\mathrm{H}$ & 2 & & & 2 \\
\hline $\mathrm{A}$ & 5 & & & 5 \\
\hline NEEDED $(\mathrm{t})$ & 23 & 23 & 23 & $69(\mathrm{t})$ \\
\hline
\end{tabular}

We act the same for the $\Delta_{33}=-23$ box and we obtain the new solution:

Table 8: Table with the new intermediate solution

\begin{tabular}{|c|c|c|c|c|}
\hline SOURCES/DEST. & KPZ31 & KPZ32 & KPZ33 & STOCK (T) \\
\hline $\mathrm{M}$ & 330 & 280 & $277 / \mathbf{1 9}$ & 19 \\
\hline $\mathrm{C}$ & $186 / \mathbf{1 8}$ & $158 / 23$ & $156 / \mathbf{2}$ & 43 \\
\hline $\mathrm{H}$ & 330 & 280 & $277 / \mathbf{2}$ & 2 \\
\hline $\mathrm{A}$ & $126 / \mathbf{5}$ & 107 & 106 & 5 \\
\hline NEEDED $(\mathrm{T})$ & 23 & 23 & 23 & $69(\mathrm{~T})$ \\
\hline
\end{tabular}

The new aim function is:

$F_{\text {min }}=0 \cdot 330+0 \cdot 280+19 \cdot 277+18 \cdot 186+$

$23 \cdot 158+2 \cdot 156+0 \cdot 330+0 \cdot 280+2 \cdot 277+5 \cdot 126+$ $0 \cdot 107+0 \cdot 106=5263+3348+3634+312+554+$ $630=13741, \quad 13741<13787$ so we can observe that the new solution is better than the previous one.

For the empty boxes, we check if the solution is already optimal by forming the $\Delta_{i j}$ differences:

$$
\begin{aligned}
& \Delta_{11}=330-277+156-186=23 \\
& \Delta_{12}=280-277+156-158=1 \\
& \Delta_{31}=330-186+156-277=23 \\
& \Delta_{32}=280-158+156-277=1 \\
& \Delta_{42}=107-126+186-158=9 \\
& \Delta_{43}=106-126+186-156=10
\end{aligned}
$$

Given the fact that all the obtained differences are positive the solution is final and optimal.

\section{Results interpretation}

The interpretation of the results for the actual plan is as it follows:

-the supply point kpz33 will receive 19 tons of ammo from source M M;

-all the supply points (kpz31, kpz32, kpz33) will receive fuel from source $\mathrm{C}$ in the next order: 18, 23 respectively 2 tons;

-the whole food quantity will be transported from the source $\mathrm{H}$ to the supply point kpz33;

-the whole quantity of water will be transported from source A to the supply point kpz31. 


\section{Conclusions}

If these operational research methods are accepted and applied within the decisional making process, it will facilitate the development of the analytical thinking among the officers, so they will be more and more adapted to the modern warfare and more rational in making decisions.

\section{References}

[1] Dumitru, V., Rugină, N., Stoian, I., Modelarea matematică a acțiunilor militare, Bacău, Editura Diagonal, 2002.

[2] Grad, V., Stoian, I., Kovacs, E., Dumitru, V., Cercetare operațională în domeniul militar, București, Editura Sylvi, 2000.

[3] Hampu, A., Căruțașu, V., Cercetări operaționale cu aplicații în domeniul militar, Sibiu, Editura Universității Lucian Blaga, 1999.

[4] Maurice, K., Operational Research in War and Peace, Londra, Editura Imperial College Press, 2003. 